\title{
剛性偏心した木質立体架構の粘弾性ダンパーによる据れ応答制御 TORSIONAL SEISMIC RESPONSE CONTROL BY VISCOELASTIC DAMPER FOR THREE-DIMENSIONAL WOOD-FRAME STRUCTURE WITH STIFFNESS ECCENTRICITY
}

\author{
山崎義弘 ${ }^{*}$, 笠井和彦**, 坂田弘安***, 大木洋司 ${ }^{* * * *}$ \\ Yoshihiro YAMAZAKI, Kazuhiko KASAI, Hiroyasu SAKATA \\ and Yoji OOKI
}

\begin{abstract}
Shaking table tests for full-scale wood frame specimens with large stiffness eccentricity are conducted. Specimen is single story, and its plan dimension is $1.82 \mathrm{~m}$ in X-direction and $2.73 \mathrm{~m}$ in Y-direction. Stiffness of specimens are unbalanced in X direction, along which input motions are provided by the shaking table. The eccentricity ratio $R_{e}$, defined by Japan Building Standard Law is about 0.6 for the standard specimen. We test six specimens : one does not have any dampers and the others are provided with viscoelastic dampers in various arrangements. The performance of specimens is discussed by referring to story drift, damper deformation and dynamic properties.
\end{abstract}

Keywords : Three-dimensional wood-frame structure, Torsional response, Stiffness eccentricity,

Passive control system, Viscoelastic damper, Shaking table test

木質立体架構, 据れ応答, 剛性偏心, 制振構造, 粘弾性ダンパー, 振動台実験

\section{1.はじめに}

\section{1 研究の背景}

1995 年の阪神・淡路大震災では、狭小な土地に建つ間口の狭い都市 型住宅や、1 階に店舗やガレージを持つことで接道面が全面開口とな った住宅において、地震時の㨭れ応答が主要因となり、倒壊あるいは 大破等の被害を受けた例が多い 1),2)。耐力要素が損傷することでエネ ルギーを吸収する耐震構造の考え方では、開口部等の構造的弱点を保 護し、㨭れ応答を効果的に抑制する手段は無いだろう。

筆者らは、地震時のエネルギー吸収能力を高めた制振壁の開発 ${ }^{3), 4}$ や、性能検証の実験 ${ }^{57-7)}$ を行い、木造住宅への制振技術の適用によっ て、効果的に応答変位を低減でき、架構の損傷を格段に抑えられるこ とを示してきた。したがって、制振部材を適切な配置、取り付け方で 設置した制振構造こそ、㨭れ応答の抑制に最も効果的であると考え、 これまでの研究の応用として剛性偏心した建物を対象に定めた。

\section{2 既往の研究}

剛性偏心が生じた木造戸建住宅に対する制振部材の適用例として、 野口らは粘弾性ダンパーを用いた地震応答制御の有効性を、立体模型 による振動台実験と地震応答解析を行なって検証した ${ }^{8)}$ 。しかし、耐 力壁を弾性として扱っている点やダンパーの取り付け方法等、実際の 木造住宅の地震時挙動を再現するために考慮しなければならない点 は多い。曽田らは小型な圧効きオイルダンパーによる制振補強》をを提 案したが、住宅 1 棟に対してダンパーが多数必要であり、㨭れを抑制 することを前提としていない。腰原・阿川らは木質面材耐力壁構造の 実大実験 ${ }^{10.11)}$ を行い、弾性域から塑性域にかけての据れ挙動を理論的
に再現する応力集中率という指標を提案し、剛性偏心と耐力偏心に関 する理論体系を確立させてきた。

筆者らは剛性だけでなく粘性の偏心も考虑した 1 層線形構造を対象 として、4 種の「㨭れの支配特性値」を定義し、これらと㨭れ応答との 関連を論じた ${ }^{12}$ 。この結果、剛性中心と粘性中心の相対的な位置関係 の違いにより、据れ応答の傾向が大きく異なることを時刻歴解析より 示した。また、その最大応答を簡易に予測する手法を提案した。この 粘性偏心の影響を加味した応答予測法および設計法は、個別の時刻歴 解析を除き、未だ存在しないのが現状である。

\section{3 研究の目的と論文の構成}

本論では粘弾性ダンパーを付加した制振壁を用いることで、付加剛 性と付加隇衰による据れ応答の抑制効果を取り上げる。木質耐力壁に 対する制振壁の特異性は、高いエネルギー吸収能力と線形性であり、 これらの特性が、剛性偏心した木質立体架構においても有効に機能す るために必要な設計法を抽出することが本論の大きな目的である。つ まり、今後増加すると考えられる制振技術の健全な普及のためには、 据れ応答を効果的に制御する制振設計法を周知・確立させる必要が あり、本論はその基䃈的研究と位置付けられる。

第 2,3 章では、既報 ${ }^{3)-5)}$ で提案した制振壁を様々な配置で設置した実 大 1 層試験体の振動台実験を行い、弾性域から塑性域にかけての最大 応答や各壁の消費エネルギーの分布を示す。第 4 章では非線形举動を 示す各壁を、等価な剛性・粘性を持つ線形モデルに置換する手法を示 し、これらのバランスと並進・据れ応答の関連を考察する。なお、本 論では水平構面は剛床仮定が成立するものとして扱う。
* 東京工業大学

日本学術振興会特別研究員 DC・修士 (工学)

** 東京工業大学建築物理研究センター 教授. Ph. D.

*** 東京工業大学建築物理研究センター 准教授. 工博

***** 東京工業大学都市地震工学センター 特任助教・修士 (工学)
JSPS Research Fellow, Tokyo Institute of Technology, M. Eng.

Prof., Struct. Eng. Res. Center, Tokyo Institute of Technology, Ph. D.

Assoc. Prof., Struct. Eng. Res. Center, Tokyo Institute of Technology, Dr. Eng.

Assistant Prof., Center of Urban Earthquake Engineering, Tokyo Institute of Technology, M. Eng. 


\section{2. 実験計画概要}

\section{1 試験体の設定}

図 1 に示すように、試験体は短辺 $(x$ 方向 $)$ が $1820 \mathrm{~mm}$, 長辺 $(y$ 方向 $)$ が $2730 \mathrm{~mm}$, 階高が $2730 \mathrm{~mm}$ の 1 層である。軸組は柱(スプルース集 成材，105×105mm)，土台(オウシュウアカマツ集成材，105×105mm), 梁 $(105 \times 180 \mathrm{~mm})$ で構成される。水平構面は剛床仮定が成立するものと し、床面の仕様を $28 \mathrm{~mm}$ 厚の構造用合板貼り(CN75 釘@75mm)とした。 振動台上に設置した鉄骨基礎梁の上に試験体の土台を固定し、ずれを 防止した。後述するが、本試験では構面ごとのせん断力を計測するた め、基礎梁および土台は構面ごとに切り離している。

耐力壁や制振壁は建物の四周に配置し、 $x$ 方向の 1 構面は大きな開 口を設けることで剛性を低下させ、この構面を「柔側」、反対の構面を 「剛側」とし、それぞれの壁を「柔側壁」、「剛側壁」と呼ぶ。また、直交 する 2 構面の壁を「直交壁」と呼ぶ。

$y$ 方向正側に剛性中心が偏心した一軸偏心建物で、振動台により $x$ 方向にのみ地震入力を与えた。質量には偏りがなく、過去の実験 ${ }^{5)-7)}$ と同様の概念に基づき、 $12 \mathrm{kN}$ の錘を積載した。なお、軸組以外の質 量は建物平面内に均等に分布していると仮定し、錘は床面に均した時 と等しい回転慣性になるように 5 箇所に分散して配置した。

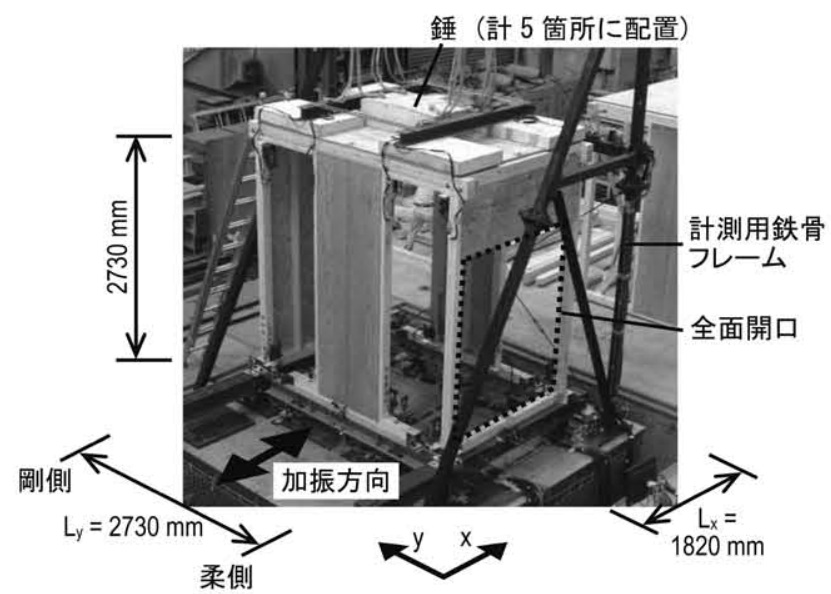

図 1 試験体のセットアップ

\section{2 実験に用いた耐力壁と制振壁の仕様}

各通りの壁立面図を図 2 に示す。耐力壁は $9 \mathrm{~mm}$ 厚の構造用合板を 釘(N50)で接合したもので、柔側壁(X1)には垂れ壁(以下、合板垂れ壁) を、剛側壁 $(\mathrm{X} 2)$ と直交壁 $(\mathrm{Y} 1, \mathrm{Y} 2)$ には全面壁(以下、合板全面壁)を用い た。制振壁はアクリル系粘弾性体 $\left.{ }^{13}\right)$ を付加したもので、柔側壁(X1)に は開口を設けた方杖型制振壁を、剛側壁 $(\mathrm{X} 2)$ と直交壁 $(\mathrm{Y} 1, \mathrm{Y} 2)$ には $\mathrm{K}$ 型制振壁を用いた。方杖型制振壁 ${ }^{5}$ には改良を加え、柱の内法に柱と 同断面の添え柱 $($ スプルース集成材, $105 \times 105 \mathrm{~mm}$ )をイソシアネート系 接着剤で接着し、さらに柱の表裏から鋼板( $2.3 \mathrm{~mm}$ 厚)をビスと接着剤 で接合し、柱の曲げ剛性を高めた。事前に行った柱の曲げ試験から、 柱 1 本 $(105 \times 105 \mathrm{~mm})$ の約 16 倍の曲げ剛性を有することを確認した。

振動台実験に先立ち行なった耐力壁の静的載荷実験と、制振壁の動 的載荷実験 ${ }^{33,5)}$ の結果を図 3 に示す。動的載荷の加振振動数の設定法 は文献 3),4)に示した通り、振幅に応じて変化させた。例えば、変形角 が $1 / 240,1 / 120,1 / 30 \mathrm{rad}$.の時、それぞれ $2.6,1.8,0.9 \mathrm{~Hz}$ とした。合板 垂れ壁はほぼ弾性に近い柱の曲げ抵抗と合板を接合している釘のせ ん断抵抗による直列系であることから、合板全面壁に比べて弾性的な
挙動である。方杖型制振壁と K 型制振壁は粘弾性ダンパーを付加した ことにより、小変形時から棈円型の履歴形状となる。さらに大変形時 にも木質構造に特有なスリップ性状はほとんど見られない。後述する が、図3(d)では実験で得たせん断力を 0.7 倍にして示している。

また、各壁の壁倍率として合板垂れ壁 $=0.4$, 合板全面壁 $=3.3$, 方 杖型制振壁 $=1.6, \mathrm{~K}$ 型制振壁 $=5$ を得た。ここで言う壁倍率とは、 $1 / 120 \mathrm{rad}$.時の耐力を基準耐力 $(=1.96 \mathrm{kN}$ ) と壁長で除した值である(付 録 1)。K 型制振壁に関しては合板全面壁に比べて剛性と耐力が非常 に高かったため、本試験では $\mathrm{K}$ 型制振壁に付加する粘弾性ダンパーの 量を、通常の 0.7 倍にした。これは、筆者らの予測法 ${ }^{3)}$ より、1/240 rad. 時の耐力が合板全面壁と等しくなるダンパー量に相当する。本制振壁 の剛性はダンパー剛性に大きく依存するため、ダンパー量を 0.7 倍に した時の履歴は、図3(d) と同等程度であると考えられる。

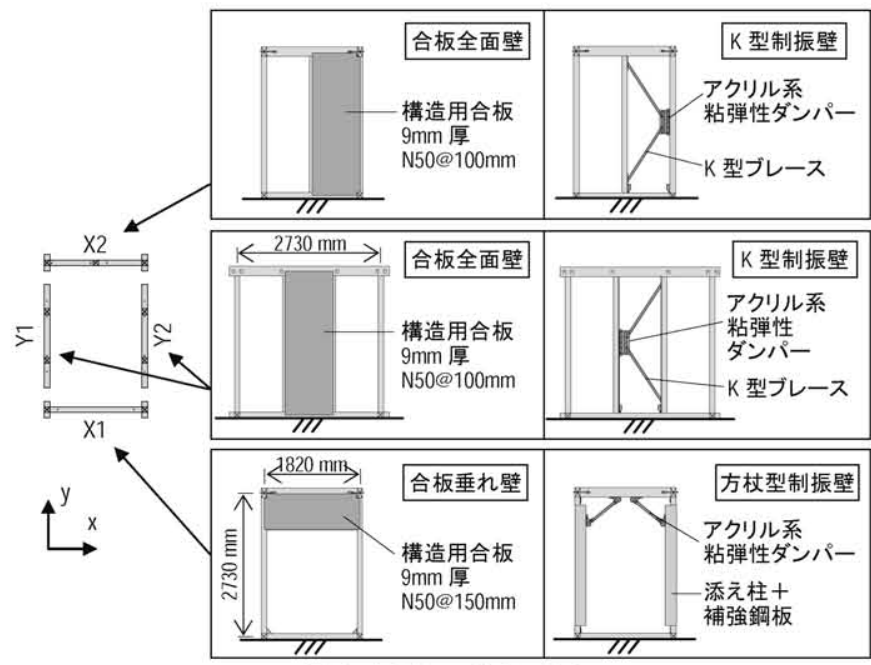

図 2 各通りの壁立面図

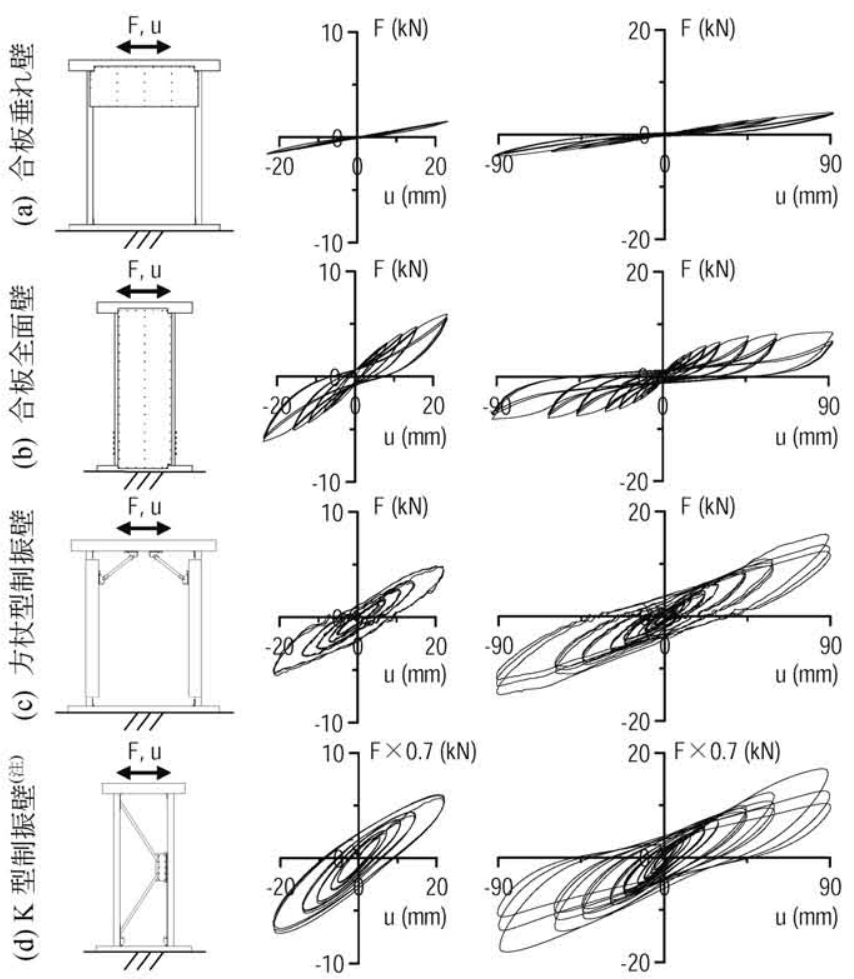

図 3 耐力壁と制振壁の単体実験結果

(注) $\mathrm{K}$ 型制振壁は実験で得たせん断力 $F$ の 0.7 倍を示している 

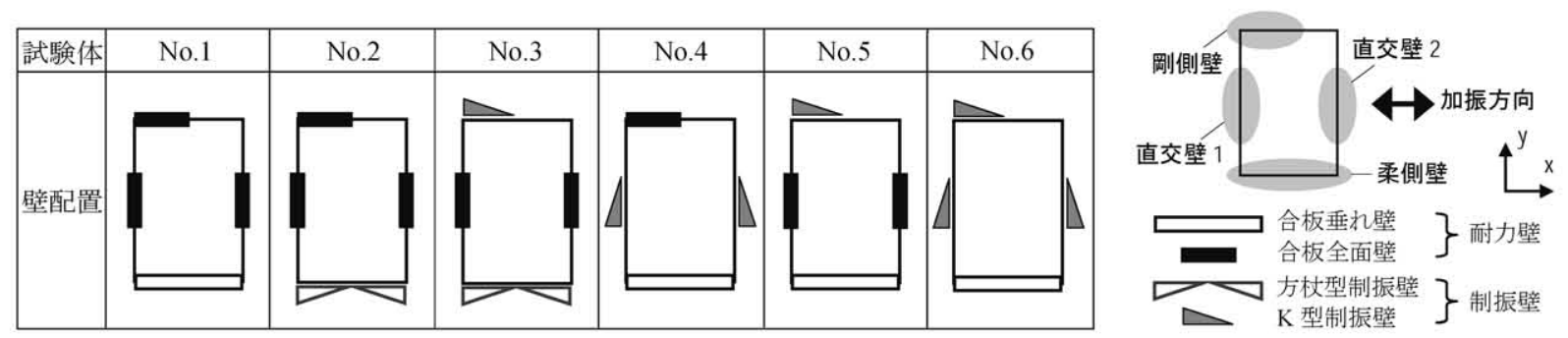

図 4 試験体一覧

\section{3 試験体パラメータと設計意図}

試験体の一覧を図 4 に示し、以下にそれぞれの設計意図を述べる。 •No.1：全ての構面が耐力壁で構成された非制振試験体である。図 3 の実験結果より算出した $1 / 200 \mathrm{rad}$. 時の割線剛性を用いて計算した結 果、剛性偏心の指標である偏心率 $R_{e x}=0.56$ であった。木造軸組構法 住宅の設計では $R_{e x} \leqq 0.3$ が要求されており、非常に大きな剛性偏心 を有していると言える。質量中心(以下、重心, center of mass) と剛性中 心(center of stiffness)が一致しないため、慣性力と復元力の合力によっ て偶力が生じ、慣性モーメントが発生する(図 5(a))。

•No.2 : 方杖型制振壁を用い、建物の構造的弱点である開口部に剛性 と粘性を付加した試験体である。重心と剛心を近付けることで前述の 偶力の発生を抑え、さらに柔側壁の粘性力によって慣性モーメントを 減衰させることで、据れを効果的に抑制するものである(図 5(b))。

•No.3 : No.2 の剛側壁を K 型制振壁にした試験体である。

•No.4 : 直交壁を K 型制振壁にすることで、㨭れを利用して減衰定数 の増加を狙った試験体である(図 5(c))。

・No.5 : 剛側壁を K 型制振壁にした試験体である。慣性力と復元力、 さらに粘性力により大きな偶力が発生し(図 5(d))、㨭れを抑えるとい

うよりは、建物の並進変位を低減させる目的である。

・No.6：剛側壁と直交壁を K 型制振壁にした試験体である。

\section{4 計測計画}

図 6 に示すように、試験体各部の変位および各壁の変形は、計測用 鉄骨フレームから試験体までの相対変位を計測し、剛床仮定に基づき

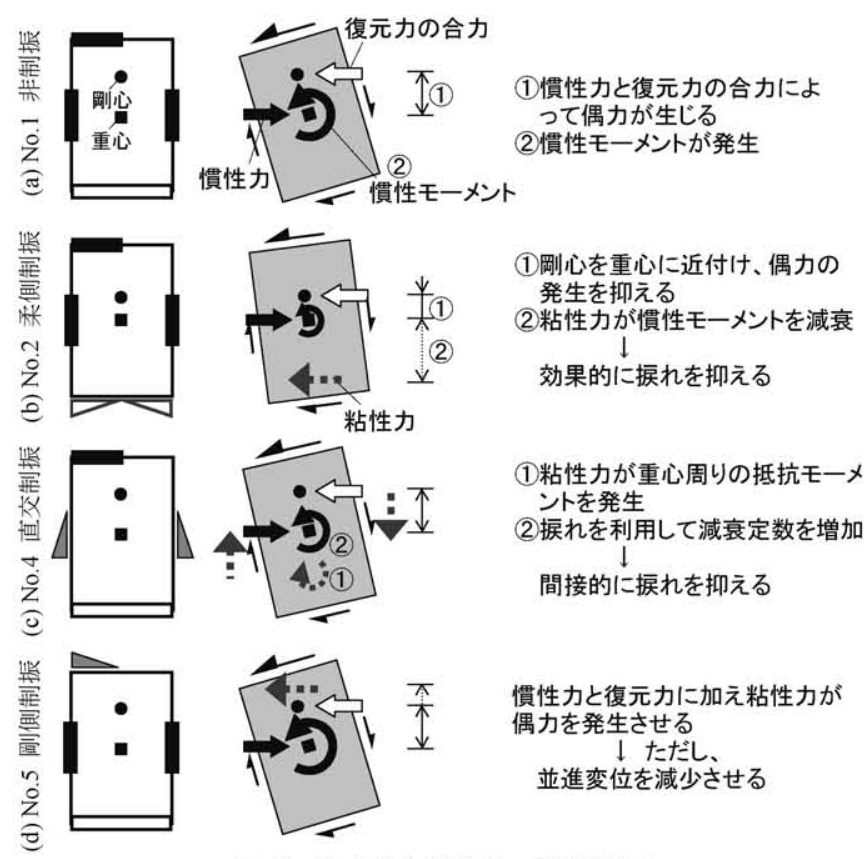

図 5 代表的な試験体の設計意図
幾何学的に求めた。なお、試験体の応答変位、加速度から剛床仮定が 妥当であることを確認している。各壁のせん断力は、基礎梁下部に設 置したせん断型ロードセルで計測されるせん断力と、土台上に設置し た加速度計で計測される試験体下部の慣性力の差から求めた。この測 定方法により、 $x$ 方向の各壁のせん断力和が、試験体上部の慣性力か ら求まる層せん断力と良好な精度で一致していることを確認した。

また、これらの他に、ダンパー変形、粘弾性体温度、柱頭・柱脚の 浮き上がり、引き寄せ金物の軸力等を計測した。粘弾性体の温度は、 各加振前に $20 \pm 0.3^{\circ} \mathrm{C}$ に収まるように管理した。

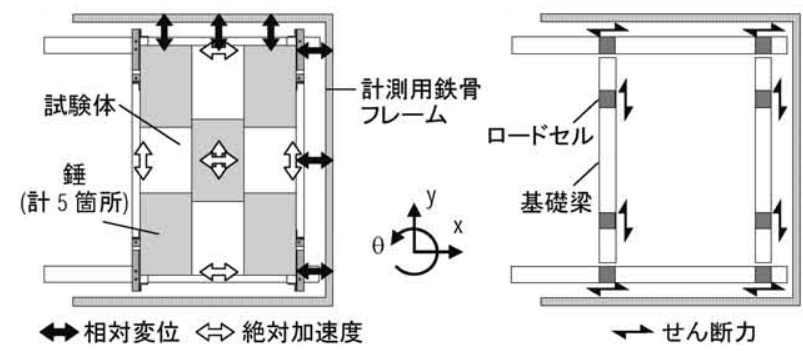

(a) 相対変位と絶対加速度 $\quad$ (b) 各壁のせん断力

図 6 試験体各部の変位とせん断力の計測

\section{5 加振スケジュール}

加振スケジュールを表 1 に示す。地震波は主要動の継続時間や卓越 周期が異なる 1995JMA Kobe NS 波と 1952Taft EW 波を採用した。ま ず、最大加速度を $0.1 \mathrm{~g}$ に基準化した神戸波（以下、0.1g 神戸波と称 し、他も同様に表記する）を入力し、次いで $0.2 \mathrm{~g}$ 神戸波、 $0.2 \mathrm{gTaft}$ 波、 $0.6 \mathrm{~g}$ 神戸波を入力した。その後、再度 $0.2 \mathrm{~g}$ 神戸波 $(0.2 \mathrm{~g}$ 神戸波(2)) を入力後、柱脚の引き寄せ金物の締め直しを行い、 $0.83 \mathrm{~g}$ 神戸波(原波) を入力した。試験体 No.2, No.3, No.6 は、その後 $1 \mathrm{~g}$ 神戸波加振も行っ た。各加振後には土台上の加速度 記録から求めた変位応答スペク トル $S_{d}$, 擬似加速度応答スペク トル $S_{p a}$ が目標波のスペクトルに 良好な精度で一致したことを確 認した。各地震入力の間には最大 加速度を $0.05 \mathrm{~g}$ に基準化したホワ イトノイズ加振(以下、WN と称 す)を行い、後述する伝達関数を 用いた動的特性評価を行った。

\begin{tabular}{|c|c|c|}
\hline 加振No. & 加振波 & 最大加速度 \\
\hline 1 & JMA Kobe NS & $0.1 \mathrm{~g}$ \\
\hline 2 & JM A Kobe NS & $0.2 \mathrm{~g}$ \\
\hline 3 & Taft EW & $0.2 \mathrm{~g}$ \\
\hline 4 & JM A Kobe NS & $0.6 \mathrm{~g}$ \\
\hline 5 & JM A Kobe NS & $0.2 \mathrm{~g}$ \\
\hline \multicolumn{3}{|c|}{ 引き寄せ金物の締め直し } \\
\hline 6 & JM A Kobe NS & $0.83 \mathrm{~g}$ (原波) \\
\hline \multicolumn{3}{|c|}{ 引き寄せ金物の締め直し } \\
\hline 7 & JMA Kobe NS & $\lg$ \\
\hline
\end{tabular}
* は試験体 No.2, No.3, No.6 で行なった (注) 各加振前後に最大加速度 $0.05 \mathrm{~g}$ の ホワイトノイズ(WN)を入力

\section{3. 実験結果}

\section{1 各壁のせん断力-変形関係}

まずは、正方向の各変位、部材力、合力の定義を図 7 に示す。変位 は重心の並進変位を $u_{x}$, 回転を $\theta$ と表す。また、本論では剛床仮定が 
成立するものとし、柔側壁・剛側壁の変位量 $u_{x 1}, u_{x 2}$ が、それぞれ $u_{x 1}=$ $u_{x}+\theta\left(L_{y} / 2\right), u_{x 2}=u_{x}-\theta\left(L_{y} / 2\right)$ となる。

2.4 節で述べたように、図 7(b)に示す各壁の反力 $\left(F_{x 1}, F_{x 2}, F_{y 1}, F_{y 2}\right)$ を 個別に計測した。また、図 7(c)に示すように、外力として $x$ 方向慣性 力 $m\left(\ddot{u}_{x}+\ddot{u}_{g}\right)$, 慣性モーメント $I \ddot{\theta}$ が生じる。ここに、 $m, I=$ 試験体上 部の質量、回転慣性、 $\ddot{u}_{\mathrm{g}}=$ 地動加速度である。これらに釣り合う合力 を、以下のように定義する。

$$
\begin{aligned}
& F_{x}=F_{x 1}+F_{x 2}, \quad m\left(\ddot{u}_{x}+\ddot{u}_{g}\right)=F_{x} \\
& M=M^{(x)}+M^{(v)}, \quad I \ddot{\theta}=M \\
& M^{(x)}=\left(F_{x 1}-F_{x 2}\right)\left(L_{y} / 2\right), \quad M^{(y)}=\left(F_{y 1}-F_{y 2}\right)\left(L_{x} / 2\right)
\end{aligned}
$$

ここに、 $F_{x}=x$ 方向層せん断力、 $M=$ 慣性モーメント、 $M^{(x)}, M^{(y)}=x$ 方 向・ $y$ 方向の壁による抵抗モーメントである。

$0.2 \mathrm{~g}$ 神戸波、 $0.6 \mathrm{~g}$ 神戸波、 $0.2 \mathrm{~g}$ 神戸波(2) そして $0.83 \mathrm{~g}$ 神戸波入力時 における各壁のせん断力-変形関係を、図 8 に示す。各加振について、 左側に柔側壁と剛側壁、右側に直交壁の履歴を示している。ただし、 直交壁(2)に関しては変形に(-1)を乗じている。
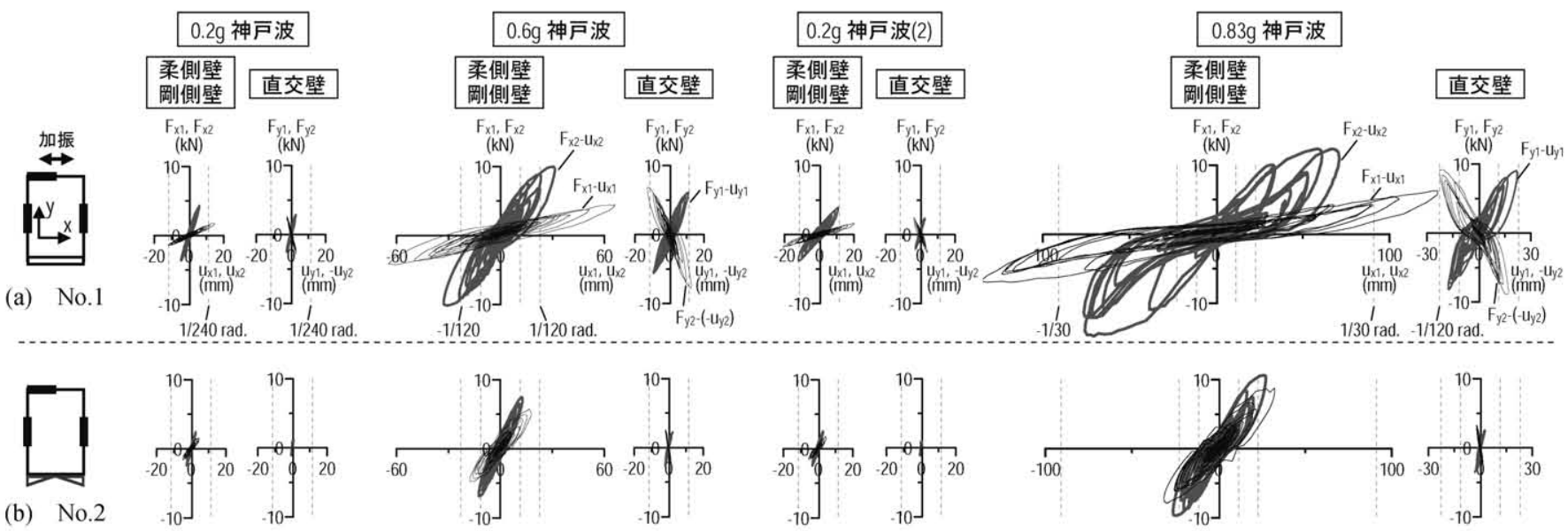

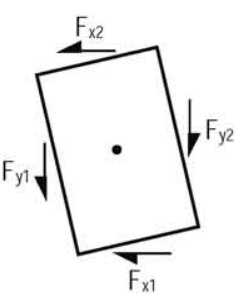

(b) 反力 $\stackrel{y}{b^{x}}$

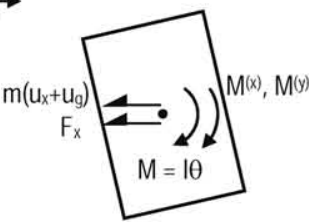

(c) 全体釣り合い式に用いる合力

各壁の変形の定義

柔側壁 $\mathrm{u}_{\mathrm{x} 1}=\mathrm{u}_{\mathrm{x}}+\theta\left(\mathrm{L}_{\mathrm{y}} / 2\right)$

剛側壁 $u_{x 2}=u_{x}-\theta\left(L_{y} / 2\right)$

直交壁(1) $\mathrm{U}_{\mathrm{y} 1}=-\theta(\mathrm{L} \times / 2)$

直交壁(2) $\mathrm{U}_{\mathrm{y} 2}=\theta(\mathrm{L} / 2)$
図 7 正方向の各変位、部材力、合力の定義
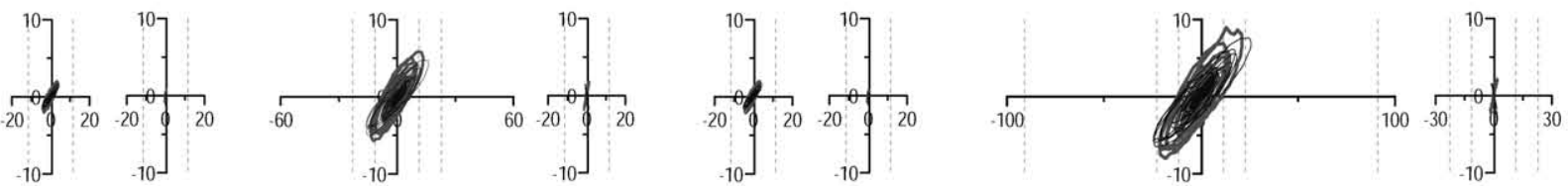

(c) No.3
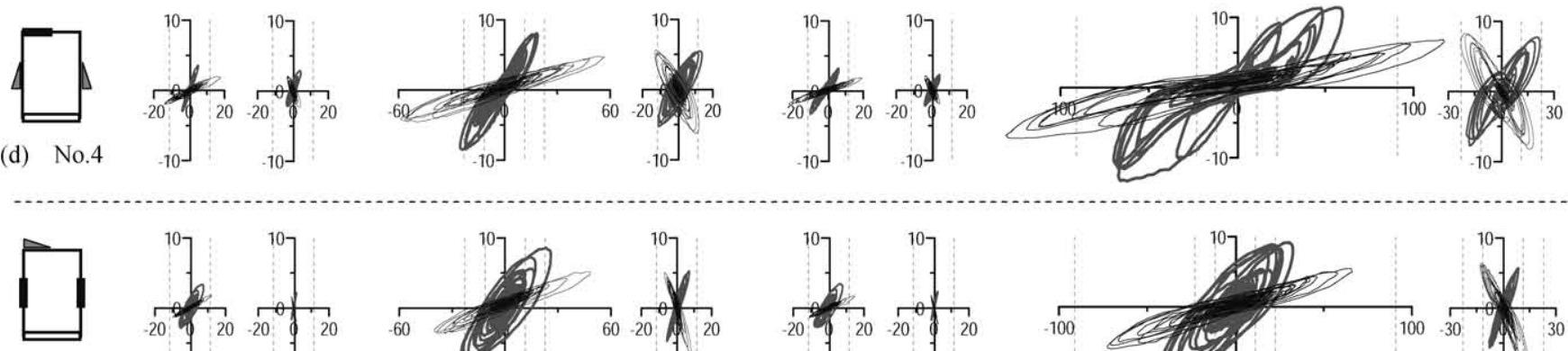

(e) No.5
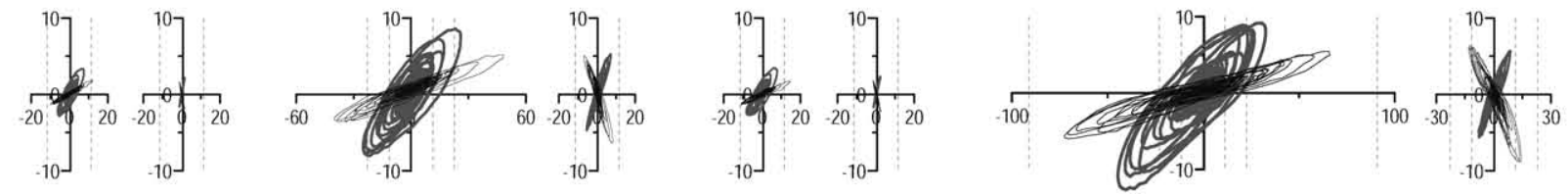

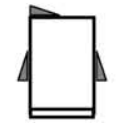

(f) No.6
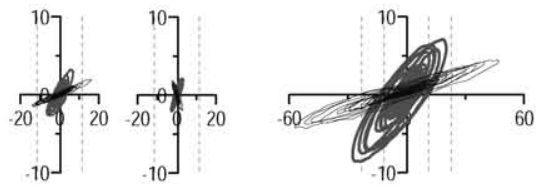

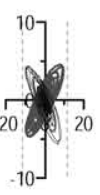

図
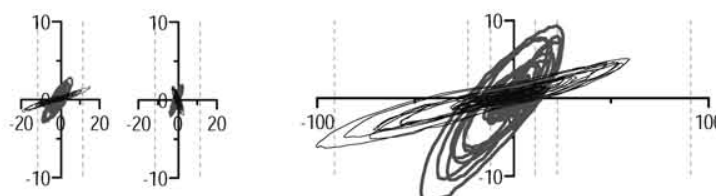

$100-30$

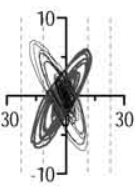


No.1 は、 $0.2 \mathrm{~g}$ 神戸波では柔側壁、剛側壁、直交壁ともに線形的な挙 動であるが、 $0.6 \mathrm{~g}$ 神戸波では柔側壁、剛側壁の剛性が劣化した。 $0.83 \mathrm{~g}$ 神戸波では、柔側壁、剛側壁の剛性劣化が進行し、さらに直交壁の最 大変形も 1/120rad.に達したことで、履歴にスリップ性状が表れている。

No. 2 と No. 3 は、柔側壁を方杖型制振壁にし、剛性と粘性を付加し たため、柔側壁の履歴の傾きが No.1 に比べて大きく上昇し、かつ太 い楕円型の形状となった。また、柔側壁と剛側壁の変形差が No.1 に 比べてかなり縮まり、直交壁の変形も小さくなった。No.2 は $0.83 \mathrm{~g}$ 神 戸波で剛側壁の変形角が 1/120rad.に達し、若干の剛性劣化が生じた。

No.4 は直交壁が棈円型の履歴であるが、柔側壁や剛側壁と比較する と、変形はかなり小さい。これは、試験体平面の辺長比が $x: y=2: 3$ であり、回転によって直交壁に生じる変形が小さいためである。

No.5 は剛側壁が非常に太い楕円型の履歴になり、多くのエネルギーを 消費した。2.2 節で述べたように、 $\mathrm{K}$ 型制振壁は 1/240rad.時に合板全 面壁と等しい耐力値となるようにダンパー量を設定していたが、本試 験での合板全面壁の剛性と耐力が図 3 で示した静的載荷実験よりも高 かったため、小変形時には $\mathrm{K}$ 型制振壁の方が剛性が低くなった。
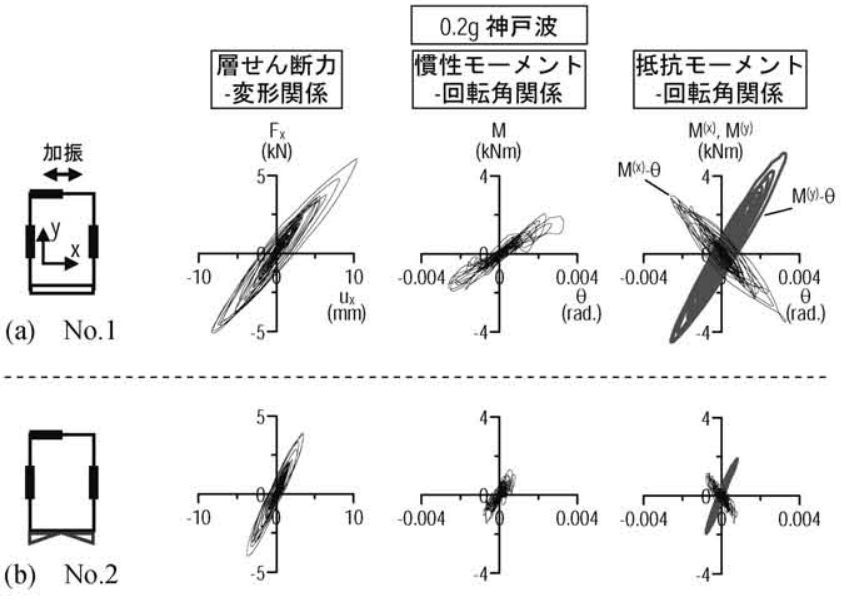

(b) No.2
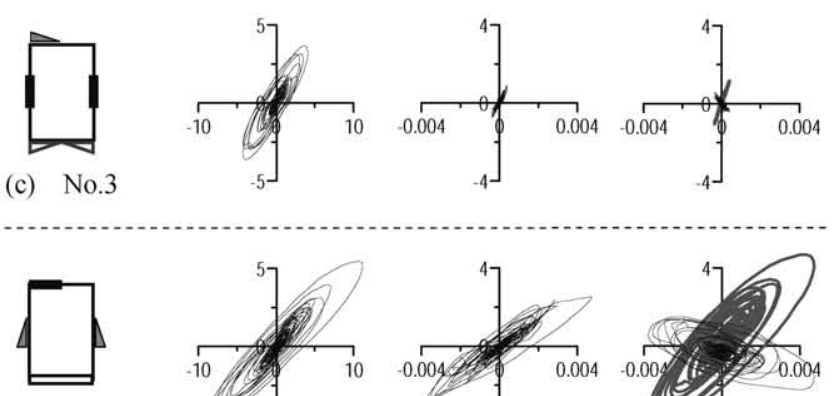

(d) No.4
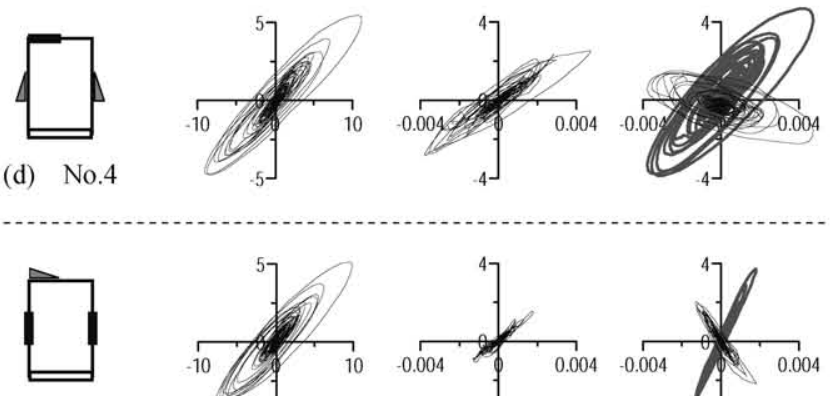

(e) No.5
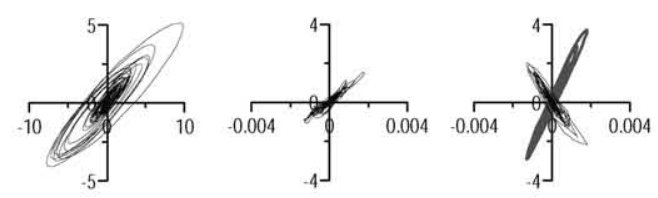

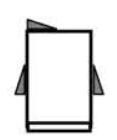

(f) No.6

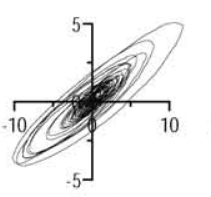

$0.2 \mathrm{~g}$ 神戸波入力時におけるシステムの全体応答

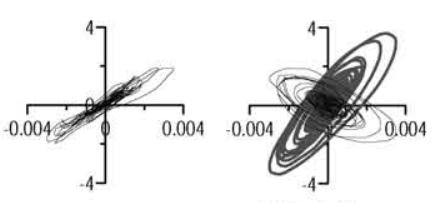

\section{2 システムの全体応答}

図 9 に $0.2 \mathrm{~g}$ 神戸波入力時におけるシステムの全体応答として、 $F_{x}-u_{x}$ 関係、 $M-\theta$ 関係、 $M^{(x)}-\theta$ 関係と $M^{(v)}-\theta$ 関係を示す。 $F_{x}-u_{x}$ 関係の傾きは 並進剛性を表し、 $M-\theta$ 関係の傾きは捩れ剛性を表す。また、全試験体 とも、ある $\theta$ に対して $M^{(x)}$ と $M^{(y)}$ が異符号となるような挙動を示した。 このような現象が生じる条件は、付録 2 で証明した。非制振の No.1 でも、小変形時から $F_{x}-u_{x}$ 関係、 $M^{(x)}-\theta$ 関係や $M^{(v)}-\theta$ 関倸は丸みを帯び、 エネルギーを消費した。これに対し、No.2 と No.3 は柔側壁への剛性 付加が、並進剛性と㨝れ剛性の上昇、さらに剛性中心を重心に近付け たことにより、 $u_{x}, \theta$ がともに減少した。No.4, No.5, No.6は No.1 に比 べて並進剛性がやや低下したが、それぞれ $F_{x}-u_{x}$ 関係が太い棈円とな り、多くのエネルギーを消費した。これらの試験体は、並進の剛性低 下と減衰付加が生じた結果、No.1 に比べて $u_{x}$ は同程度となり、 $F_{x}$ は やや低下した。No.4 は直交壁の制振化のみで、並進の減衰性能が高ま ったことが分かる。また、直交壁を制振化した No.4, No.6 は、 $M^{(x)}-\theta$ 関係と $M^{(v)}-\theta$ 関係が太い楕円となり、多くのエネルギーを消費した。

\section{3 最大応答変位}

次に、 $0.1 \mathrm{~g}$ 神戸波、 $0.2 \mathrm{~g}$ 神戸波、 $0.6 \mathrm{~g}$ 神戸波、および $0.83 \mathrm{~g}$ 神戸波 入力時の、柔側壁・剛側壁の最大応答変位 $u_{x 1, \text { max }}, u_{x 2, \text { max }}$ を図 10 にまと めた。横軸は試験体 No.を表し、0.83g 神戸波入力時に重心の変位が小 さかった順にNo.3, No.2, No.5, No.6, No.4, No.1 と並べ替えた。また、 縦軸は対数軸で表している。

全加振を通して、No.2 と No.3 は他の試験体に比べて変位が低減さ れ、据れも小さくなった。No.4 は全加振を通してNo.1 とほぼ同程度 の変位であった。No.5, No.6 は、小加振時にはNo.1 と同程度の変位で あるが、 $0.83 \mathrm{~g}$ 神戸波加振時では柔側・剛側ともに変位がやや低減さ れたが、No.2, No.3 ほどの大きな効果はなかった。

次に、 $0.2 \mathrm{~g}$ 神戸波の 1 回目と 2 回目の結果を図 11 に示す。全試験 体とも、2 回目は既に $0.6 \mathrm{~g}$ 神戸波を経験したことで架構が非線形化し、 変位が大きくなった。しかし、No. 2 やNo.3 は上述した㨭れ応答の抑 制により木質架構の損傷が抑えられ、2 回目の加振での変位上昇が非 常に少ないことが分かる。図 12 は $0.2 \mathrm{~g}$ 神戸波と $0.2 \mathrm{gTaft}$ 波の変位応 答スペクトル $S_{d}$ の比較である。これより、両加振の応答量に大差はな いと言える。図 12 には、後述する等価線形化による固有值解析 $(4.2$ 節)より得た 1 次固有周期と減衰定数を用い、時刻歷解析から得た応 答推定値も併せて示した。木質住宅のような短周期構造物は、変位が 周期の 2 乗に比例する傾向にあり、No. 2 と No. 3 は短周期化により変 位が著しく低減された。No.4, No.5, No.6はNo.1 に比べて長周期化し ているが、付加減衰により変位の上昇が抑えられている。

\section{4 最大応答加速度}

本節では、 $0.2 \mathrm{~g}$ 神戸波、 $0.83 \mathrm{~g}$ 神戸波入力時の最大応答加速度(絶対 加速度)として Case1, Case2 の 2 種ケースの応答を示す。Case1 では並 進加速度 $\left(\ddot{u}_{x}+\ddot{u}_{g}\right)=\max$ となる時刻での $\left(\ddot{u}_{x}+\ddot{u}_{g}\right)_{\max }$ と $\ddot{\theta}_{\max 1}$ を、Case2 では角加速度 $\ddot{\theta}=\max$ となる時刻での $\ddot{\theta}_{\text {max } 2}$ を表 2 に示した。

全体的に、各試験体の㨭れの大小は応答変位の傾向と類似している。 また、 $\ddot{\theta}_{\max 1}$ と $\ddot{\theta}_{\max 2}$ は必ずしも等しくなく、重心の並進加速度が最大 となるのとは異なる時刻で、大きな角加速度が生じる。特に、 $0.83 \mathrm{~g}$ 神戸波入力時のような塑性域では、 $\ddot{\theta}_{\max 1}$ に比べて $\ddot{\theta}_{\max 2}$ が非常に大き くなった。No.1 は $8.79 \mathrm{rad} / \mathrm{s}^{2}$ となり、これを直交壁での $y$ 方向並進加 速度に換算すると、 $800 \mathrm{~cm} / \mathrm{s}^{2}$ となる。振動台による $x$ 方向への入力 


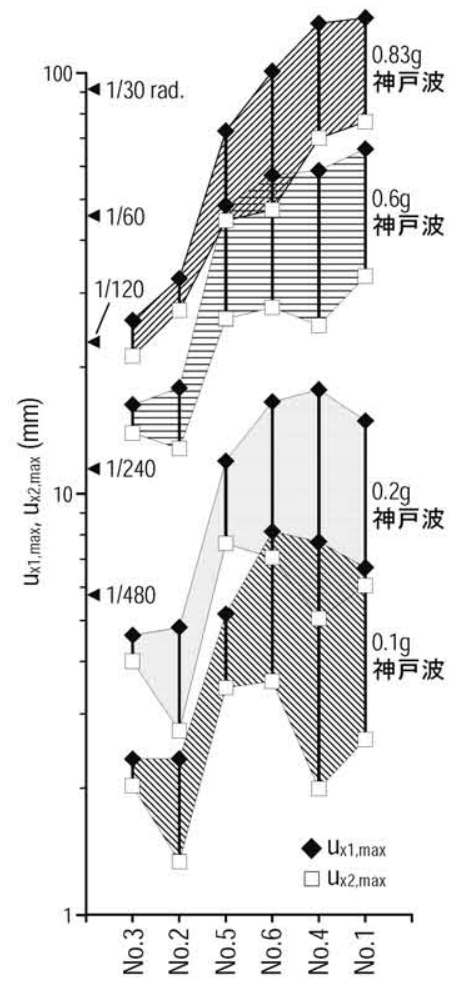

図 10 神戸波入力時の 最大応答変位の比較

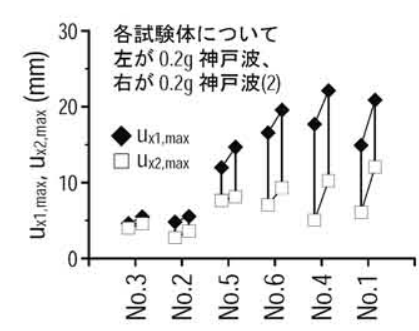

図 $110.2 \mathrm{~g}$ 神戸波加振における 1 回目と 2 回目の応答変位比較

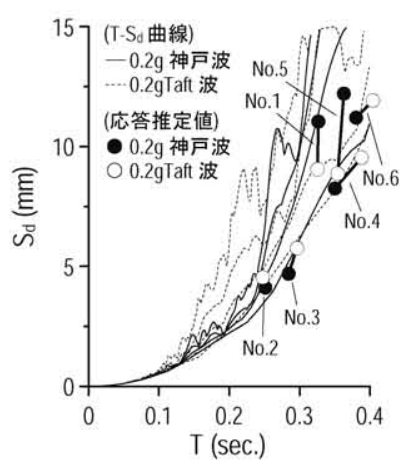

図 12 神戸波と Taft 波の 変位応答スペクトル $S_{d}$

表 2 重心の最大応答加速度

\begin{tabular}{c|c|c|c|c|c|c}
\hline \multirow{2}{*}{ 試験体 } & \multicolumn{3}{|c|}{$0.2 \mathrm{~g}$ 神戸 } & \multicolumn{3}{|c}{$0.83 \mathrm{~g}$ 神戸 } \\
\cline { 2 - 7 } & \multicolumn{2}{|c|}{ Case1 } & Case2 & \multicolumn{2}{|c}{ Case1 } & Case2 \\
\cline { 2 - 7 } & $\left(\ddot{i}_{x}+\ddot{i}_{s}\right)_{\max }$ & $\ddot{\theta}_{\max 1}$ & $\ddot{\theta}_{\max 2}$ & $\left(\ddot{i}_{x}+\ddot{i}_{s}\right)_{\max }$ & $\ddot{\theta}_{\max 1}$ & $\ddot{\theta}_{\max 2}$ \\
\hline No.1 & 384 & 0.70 & 1.14 & 1509 & 2.76 & 8.79 \\
\hline No.2 & 258 & 0.09 & 0.68 & 1271 & -0.58 & 3.65 \\
\hline No.3 & 246 & 0.17 & 0.30 & 1083 & 0.64 & 0.91 \\
\hline No.4 & 358 & 0.92 & 1.12 & 1385 & 2.26 & 7.36 \\
\hline No.5 & 336 & 0.50 & 0.56 & 1235 & 0.21 & 4.02 \\
\hline No.6 & 326 & 0.73 & 0.86 & 1290 & 1.19 & 4.13 \\
\hline \hline
\end{tabular}

Case1：重心加速度 $\left(\ddot{\mathrm{u}}_{\mathrm{x}}+\mathrm{u}_{g}\right)=\max$ のとき，Case2：重心角加速度 $\ddot{\theta}=\max$ のとき $\left(\ddot{u}_{x}+\ddot{u}_{g}\right)_{\text {max }}$ : 重心の最大加速度 $\mathrm{cm} / \mathrm{s}^{2}$

$\ddot{\theta}_{\max }, \ddot{\theta}_{\max 2}$ ：重心の最大角加速度 rad./s² (それぞれ Case1, Case2を表す)

加速度の最大值がおよそ $821 \mathrm{~cm} / \mathrm{s}^{2}$ であることを考慮すれば、非常に 大きな加速度が直交壁にも加わることが分かる。Case2 のような大き な角加速度が直交壁の損傷をもたらすため、注意が必要である。また、 No. 2 の $\ddot{\theta}_{\text {max } 1}<0$ となり、剛側壁に最も大きな加速度が生じた。

\section{5 各壁の消費エネルギー}

本節は各壁が消費したエネルギー量の検討を行うが、その前に、後 述する固有值解析より算出した 1 次固有周期 $T_{1}$ と入力エネルギーの速 度換算值 $V_{e}$ の関係を図 13 に示す。ここで、入力エネルギーは各壁の せん断力-変形関係の履歴面積の総和から求めた。周知のように、木 質住宅が属する短周期領域では $T_{1}$ と $V_{e}$ が概ね比例関係にある。本論 で対象としたような非比例減衰系においても、上記傾向が見られた。 したがって、1 次モードの短周期化は、応答変位とともに系への入力 エネルギーを減らす効果がある。

次に、 $0.2 \mathrm{~g}$ 神戸波と $0.83 \mathrm{~g}$ 神戸波入力時の、入力エネルギーに対す る、各壁が消費したエネルギーの割合を図 14 に示す。ここで、耐力 壁の消費エネルギーは釘の塑性変形や木材のめり込み等の損傷と考

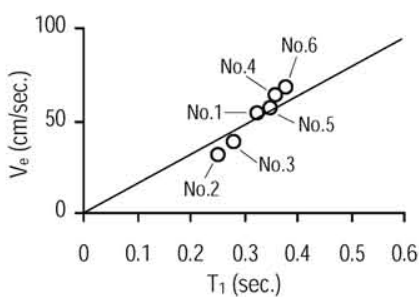

(a) $0.2 \mathrm{~g}$ 神戸波

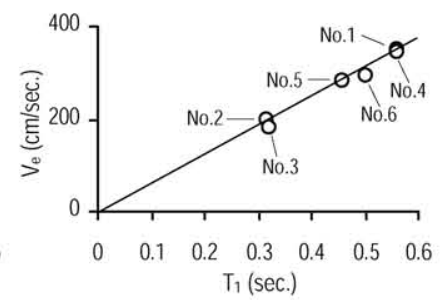

(b) $0.83 \mathrm{~g}$ 神戸波
図 13 試験体の 1 次固有周期と入力エネルギーの速度換算値

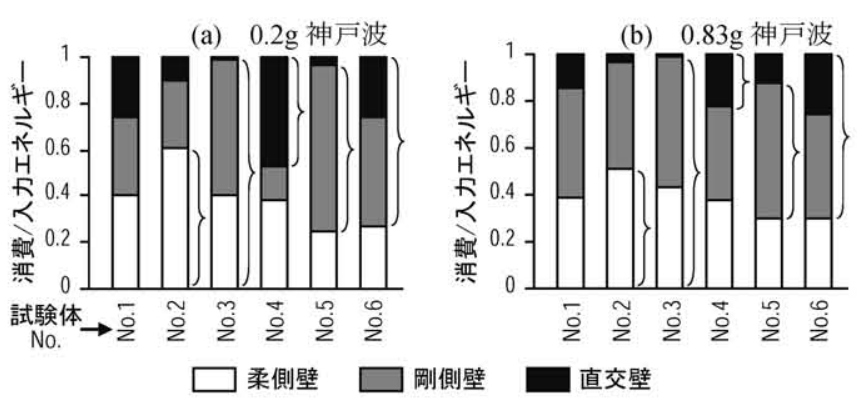

図 14 各壁が消費したエネルギーの割合

(波括弧は制振壁による消費エネルギーの分担である)

えることができる。一方、方杖型制振壁は壁全体の消費エネルギーに 対するダンパーの消費エネルギーが $60 \sim 80 \%$ であり、 $\mathrm{K}$ 型制振壁では 80〜90\%であったことを別途確認している。ゆえに、制振壁の消費エ ネルギーは、その大部分が粘弾性ダンパーにより熱エネルギーに変換 され、ダンパー構面の他の要素におよぶ損傷を抑えたと解釈できる。

$0.2 \mathrm{~g}$ 神戸波入力では、No.1 は柔側耐力壁に約 $40 \%$ の消費エネルギー が集中した。No.2 の柔側制振壁と No.5 の剛側制振壁は、それぞれ約 60,70\%を、No.4 は直交制振壁であるにも関わらず、約 $50 \%$ のエネル ギーを消費した。No.3 は柔側制振壁と剛側制振壁でほぼ $100 \%$ を消費 した。これに対し、0.83g 神戸波入力では、耐力壁の損傷に伴う履歷 吸収エネルギーが増加する。No.4 は柔側耐力壁と剛側耐力壁の損傷を 防ぐことができず、制振壁で消費したエネルギーの割合が減少した。

\section{4. 並進・㨭れ応答と剛性・粘性のバランスに関する考察}

前章の実験結果より、試験体の最大応答量とその分布は、各壁の剛 性と粘性の量やバランスによって大きく異なることが分かった。本章 では、本来非線形である各壁の剛性と粘性を線形として扱う手法を示 し、システムの応答との関連を考察する。

\section{1 伝達関数を用いた固有周期と減衰定数の評価}

加振時に得られた加速度記録から伝達関数を求め、試験体の固有周 期と減衰定数を評価した結果を示す。試験体の土台上で計測した加速 度記録を入力、屋根面上の重心位置で計測した加速度記録を出力とし、 それぞれのフーリエスペクトルの比から伝達関数を求める。ここで得 た伝達関数に、比例減衰系を仮定した線形 2 自由度系の理論伝達関数 を最小二乗法によりカーブフィットさせることで、試験体の 1 次・2 次固有周期 $T_{1}, T_{2}$, および減衰定数 $h_{1}, h_{2}$ を得た(付録 3$)$ 。こで、全試 験体で 1 次モードは $x$ 方向並進が卓越し、2 次モードは回転が卓越し たモードであった。また、 $T_{2}$ は 0.1 秒程度であり、図 12 から 2 次モー ドの変位応答への影響が極めて少ないと考えられる。したがって、以 下では全て 1 次モードの結果について言及する。

$0.1 \mathrm{~g}$ 神戸波, $0.2 \mathrm{~g}$ 神戸波, $0.6 \mathrm{~g}$ 神戸波, $0.83 \mathrm{~g}$ 神戸波と、これらの前後 に行った WN 加振で得た $T_{1}$ と $h_{1}$ を表 3 , 表 4 に示す。表中の神戸波加 
振の括弧内の值は、後述する固有值解析より得た值である。3.3 節で 述べたように、No.2 と No.3 は短周期になり、減衰も付加された。神 戸波入力の前後の WN 加振の結果から、 $T_{1}, h_{1}$ ともにほぼ変化がなく、 各要素が神戸波加振後も健全な状態に保たれたことが分かる。No.2 は $0.83 \mathrm{~g}$ 神戸波入力時に $T_{1}$ の伸び、 $h_{1}$ の上昇が見られるが、これは粘 弾性体の温度上昇による軟化が原因であると考えられる。No.1, No.4, No.5, No.6 は $0.6 \mathrm{~g}, 0.83 \mathrm{~g}$ 神戸波で $T_{1}$ の伸びや $h_{1}$ の上昇が著しく、大き く損傷した。ゆえに、最も変形が大きい柔側壁の制振化により㨭れ応 答を抑制しなければ、架構を無損傷に保つことはできないと言える。

表 3 , 表 4 の $T_{1}, h_{1}$ と、伝達関数より求まる刺激関数を用いて実験の 最大変位を予測した結果、全加振・試験体で平均的に 2 割程度小さく なることを別途確認した。また、並進応答に対する㨭れ応答の割合も 実験結果と異なっていた。次節では、より精度の高い等価線形化手法 を提案し、これに基づく検討を行う。

表 3 伝達関数より算出した試験体の 1 次固有周期 $T_{1}$ (括弧内は 4.3 節の固有値解析結果)

\begin{tabular}{|c|c|c|c|c|c|c|c|}
\hline \multirow{2}{*}{\multicolumn{2}{|c|}{$\frac{\text { 入力波 }}{\text { Maxacc. }(\mathrm{g})}$}} & \multirow{2}{*}{$\begin{array}{l}\mathrm{WN} \\
0.05 \\
\end{array}$} & \multicolumn{4}{|c|}{ 神戸波 } & \multirow{2}{*}{$\begin{array}{l}\mathrm{WN} \\
0.05 \\
\end{array}$} \\
\hline & & & 0.1 & 0.2 & 0.6 & 0.83 & \\
\hline \multirow{6}{*}{$\frac{\sum^{\circ}}{\frac{14}{4}}$} & 1 & 0.27 & $0.28 \quad(0.31)$ & $0.30 \quad(0.33)$ & $0.38 \quad(0.46)$ & $0.50 \quad(0.56)$ & 0.42 \\
\hline & 2 & 0.23 & $0.24 \quad(0.25)$ & $0.23 \quad(0.25)$ & $0.26(0.29)$ & $0.32 \quad(0.32)$ & 0.24 \\
\hline & 3 & 0.25 & $0.24 \quad(0.27)$ & $0.24 \quad(0.28)$ & $0.25 \quad(0.33)$ & $0.26(0.32)$ & 0.27 \\
\hline & 4 & 0.30 & $0,31 \quad(0,32)$ & $0.32(0.36)$ & $0.41 \quad(0.45)$ & $0.50 \quad(0.56)$ & 0.44 \\
\hline & 5 & 0.28 & $0.29 \quad(0.34)$ & $0.30 \quad(0.35)$ & $0.35 \quad(0.41)$ & $0.40(0.46)$ & 0.31 \\
\hline & 6 & 0.32 & $0.33 \quad(0.38)$ & $0.35 \quad(0.38)$ & $0.40(0.47)$ & $0.44 \quad(0.50)$ & 0.36 \\
\hline
\end{tabular}

表 4 伝達関数より算出した試験体の 1 次減衰定数 $h_{1}$ (括弧内は 4.3 節の固有值解析結果)

\begin{tabular}{|c|c|c|c|c|c|c|c|}
\hline \multirow{2}{*}{\multicolumn{2}{|c|}{$\frac{\text { 入力波 }}{\text { Maxacc. (g) }}$}} & \multirow{2}{*}{$\frac{\mathrm{WN}}{0.05}$} & \multicolumn{4}{|c|}{ 神戸波 } & \multirow{2}{*}{$\begin{array}{l}\mathrm{WN} \\
0.05\end{array}$} \\
\hline & & & 0.1 & 0.2 & 0.6 & 0.83 & \\
\hline \multirow{6}{*}{ 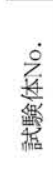 } & 1 & 2.2 & $\begin{array}{ll}5.6 & (6.7) \\
\end{array}$ & $\begin{array}{ll}4.8 \quad(10.7) \\
\end{array}$ & $14.7(17.1)$ & $12.7(15.5)$ & 15.0 \\
\hline & 2 & 5.6 & $\begin{array}{ll}7.5 & (7.9) \\
\end{array}$ & $9.3 \quad(13.2)$ & 14.9 (21.6) & $24.6(21.9)$ & 6.3 \\
\hline & 3 & 14.0 & $16.7(14.0)$ & $16.6(24.6)$ & $18.5 \quad(33.9)$ & $20.6(32.0)$ & 14.1 \\
\hline & 4 & 8.6 & $8.8 \quad(10.4)$ & $10.9(13.8)$ & $19.5(18.7)$ & $12.4(17.5)$ & 16.0 \\
\hline & 5 & 12.2 & $13.4(15.7)$ & $12.7(22.3)$ & $20.6(23.1)$ & $24.6(23.6)$ & 12.6 \\
\hline & 6 & 12.7 & $14.7(12.0)$ & $16.2(17.0)$ & $17.2(24.0)$ & $18.0(24.4)$ & 15.1 \\
\hline
\end{tabular}

\section{2 線形構造への近似手法とその精度}

スリップ型履歴を有する木質耐力壁と粘弾性ダンパーを持つ制振 壁を、統一的に Kelvin モデルに置換する手法を以下に示す。図 8 で示 した各壁のせん断力-変形関係は、木質耐力壁・制振壁を問わず、変形 の増大に伴い少なからず剛性が低下した。そこで、壁の剛性は各加振 の最大変形時の割線剛性で定義する(図 15)。また、壁のせん断力-速度 関係の傾きを最小二乗法で求め、これを粘性係数とした ${ }^{14)}$ (図 16)。な お、各壁の速度は変形の微分より得た。図 15 , 図 16 は $0.83 \mathrm{~g}$ 神戸波入 力時における壁の剛性、粘性係数の評価例であり、(a)は No.1 の合板 垂れ壁、(b)は No.2 の方杖型制振壁の履歴である。制振壁はスリップ 性状がほとんど見られず、線形的な挙動であることが分かる。

本手法の精度を検証するため、図 17 に示す平面解析モデルにより 時刻歴解析を行った。このモデルは第 2,3 章の振動台実験を再現する もので、剛床を表す平面板に質量を 4 分割して配置し、各壁を表す Kelvin モデルを接続したものである。試験体の回転慣性を考慮し、重 心(図心)から後述する $r_{m}$ (式(3c))離れた位置に質量を配置した。

解析結果の例を図 18 に示寸。入力は $0.2 \mathrm{~g}, 0.83 \mathrm{~g}$ 神戸波であり、 試験体 No.1 を対象とした。図 18 (a)は柔側耐力壁と剛側耐力壁の履歷
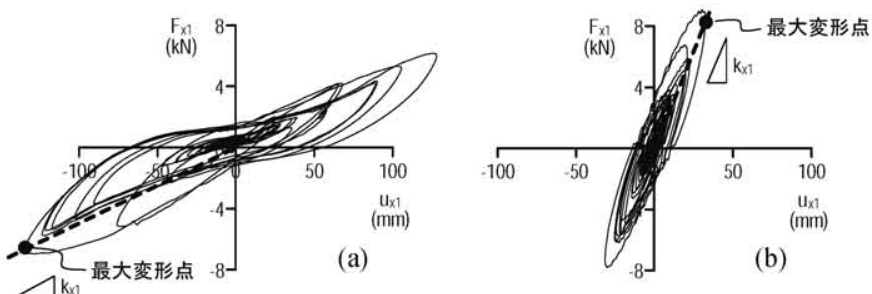

図 15 壁の剛性の評価 (例 : $0.83 \mathrm{~g}$ 神戸波入力) (a) No.1 合板垂れ壁、(b) No.2 方杖型制振壁

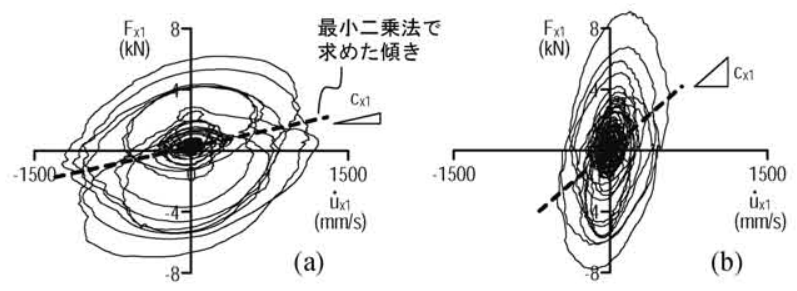

図 16 壁の粘性係数の評価 (例 : $0.83 \mathrm{~g}$ 神戸波入力) (a) No.1 合板垂れ壁、(b) No.2 方杖型制振壁

を実験結果と比較している。線形 に置換した解析モデルでも実験の 最大変形を概ね捉えている。図 18 (b)は重心変位 $u_{x}$ の時刻歴を示し ている。各壁の最大変形時の割線 剛性を用いたため、最大変形を経 験するまでは解析の周期が短めと なるが、最大変形を経験後は解析 と実験の周期が類似している。紙 面の都合上割愛するが、制振壁は

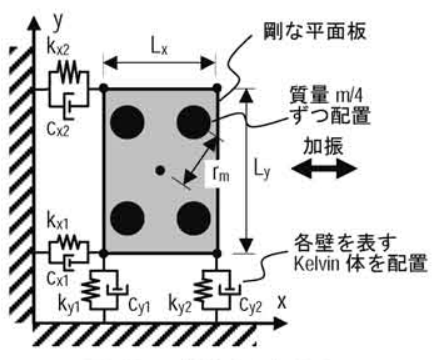

図 17 実験を再現する 平面解析モデル 線形性が強いため、実験結果の予測精度も良好であった。全試験体・ 加振で精度を調べた結果、 $20 \%$ 以内の誤差で最大変位を予測できた。

このように、強い非線形性を有する木質構造においても、最大変形 を高精度で予測可能な等価な線形構造への近似が可能であることが 分かった。また、上述の手法で求まる各壁の剛性と粘性係数を用い、 実固有值解析により得た $T_{1}$ と $h_{1}$ を、表 3 , 表 4 の括弧内に示した。こ れらは後述する式(5), 付録 4 の式(A3)より求まる。ただし、WN 加振 では応答変位が小さかったため評価していない。伝達関数より得られ る評価值に比べて、 $T_{1}$ は長めに、 $h_{1}$ は大きめになる傾向がある。

\section{31 層偏心建物の動的特性}

前節のような手法で線形構造への置換が概ね妥当であったため、筆 者らが文献 12)で示した線形理論に基づく 1 層偏心建物の動的特性を 導出する。ここでは重要な式のみを示しておく。まず、変位べクトル u を次のように定義する。

$$
\begin{aligned}
& \mathbf{u}=\left\{\begin{array}{ll}
u_{x} & \Delta u_{x}
\end{array}\right\} \\
& \Delta u_{x}=r_{m} \theta, \quad r_{m}=\sqrt{I / m}
\end{aligned}
$$

$\Delta u_{x}$ は重心から回転半径 $r_{m}$ 離れた点の、重心に対する $x$ 方向相対変位 であり、3.1節で定義した $\Delta u_{x 1}, \Delta u_{x 2}$ との関倸は、

$$
\Delta u_{x 1}=\Delta u_{x 2}=\Delta u_{x}\left\{\left(L_{y} / 2\right) / r_{m}\right\}
$$

減衰項を無視した実固有值問題を解くことで、1 次モードの固有円 振動数 $\omega_{1}$, 固有ベクトル $\phi_{1}$, 刺激係数 $\beta_{1}$ は次式のように得られる ${ }^{12)}$ 

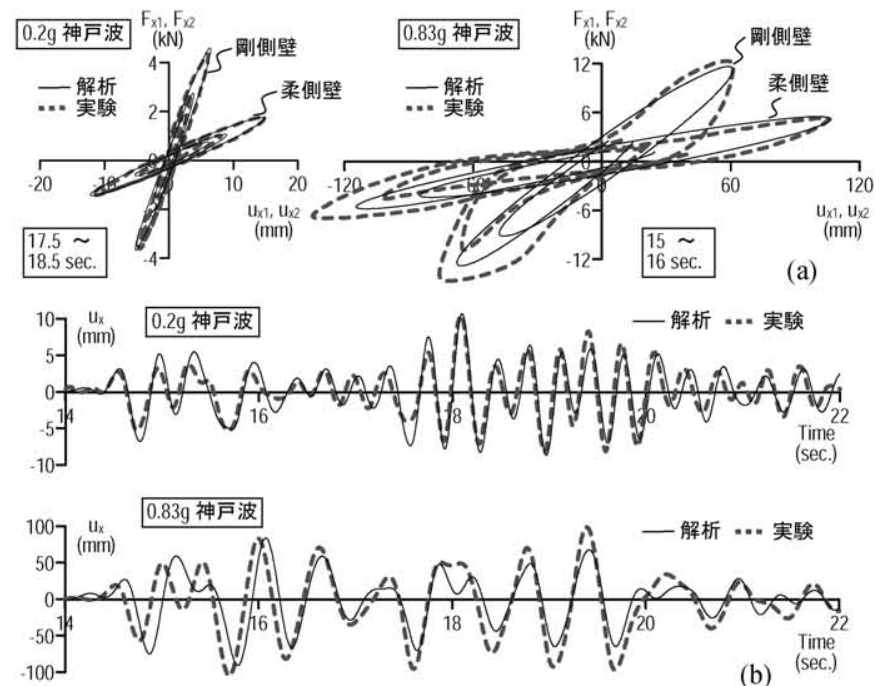

(b) $(\mathrm{sec}$

図 18 線形に置換した解析と実験結果の比較 (No.1の例) (a) 柔側耐力壁と剛側耐力壁の履歴 (b) 重心変位 $u_{x}$ の時刻歴

$$
\begin{aligned}
& \omega_{1}^{2}=\frac{1}{2} \omega_{x}^{2}\left[1+\left(\frac{\omega_{\theta}}{\omega_{x}}\right)^{2}-\sqrt{\left\{1+\left(\frac{\omega_{\theta}}{\omega_{x}}\right)^{2}\right\}^{2}-4\left\{\left(\frac{\omega_{\theta}}{\omega_{x}}\right)^{2}-\bar{e}_{y}^{2}\right\}}\right] \\
& \phi_{1}=\left\{\begin{array}{l}
\phi_{11} \\
\phi_{21}
\end{array}\right\}=\left\{\begin{array}{c}
1 \\
\beta_{1}=\phi_{11} /\left(\phi_{11}^{2}+\phi_{21}^{2}\right)
\end{array}\right.
\end{aligned}
$$

式(5)中の $\bar{e}_{y}, \omega_{\theta} / \omega_{x}$ は文献 12)で定義した 4 種の据れの支配特性值の うち、剛性に関する 2 種パラメータである。それぞれの物理的な意味 は、 $\bar{e}_{y}=$ 剛性偏心の大きさ、 $\omega_{\theta} / \omega_{x}=$ 並進の円振動数と㨭れの円振 動数の比であり、各壁の剛性の大きさと位置や、質量分布より求まる。 式(5)より、 $\omega_{\theta} / \omega_{x}$ が小さく、 $\bar{e}_{y}$ が大きいほど $\omega_{1}$ は低下し、応答変位 の増加に繋がる。すなわち、据れ剛性の低下や剛性偏心の増加は、固 有べクトルの㨭れ成分 $\phi_{21}$ だけでなく、建物全体の変位を増大させるた

め、木質住宅の据れ応答を制御する必要性は極めて高いと言える。

\section{4 各試験体の剛性・粘性のバランス}

等価線形化によって得た各試験体の剛性・粘性のバランスを図 19 に示す。剛性・粘性の大きさを、それぞれ黒と白の長方形の長さで表 した。粘性の大きさは、粘性係数 $c$ と式(5)の $\omega_{1}$ を用い、壁単体の等価
減衰定数 $h_{e q}=c \omega_{1} /(2 k)=0.2$ のときに剛性と等しい長さとした ${ }^{14)}$ 。ただ し、 $c \omega_{1}$ は一般に損失剛性を表すが、本論では単に粘性と呼ぶ。また、 剛性中心、粘性中心の位置と、式(6)より求まる 1 次モード形も併せて 示した。モード形は全ての試験体で重心変位 $=1$ に基準化し、柔側壁 と剛側壁の変位を図中に示した。つまり、並進応答に対する据れ応答 の比を各試験体で比較している。対象とした入力地震動は概ね弾性域 と言える $0.2 \mathrm{~g}$ 神戸波と、塑性域である $0.83 \mathrm{~g}$ 神戸波の 2 波とした。

柔側壁に剛性を付加した(No.2, No.3)は剛性中心が重心に近くなり、 No.1 に比べてモード形の据れが小さい。No.5 は剛性中心が比較的重 心に近く、同様に据れが小さくなった。ゆえに、まずは剛性中心を重 心に近付けることが、㨭れの抑制に繋がる。No.4, No.6 は直交壁の岡 性が低く、モード形の据れがやや大きくなった。直交壁の剛性を高め ることも据れ応答を抑制することは知られているが、その影響の度合 いは辺長比に依存する。付録 2 に示寸手法を用いて、直交壁の剛性が 据れ剛性に寄与する割合を計算した ${ }^{12}$ 。例えば、 $0.2 \mathrm{~g}$ 神戸波の No.1 の剛性バランスを用いると、本論の試験体のように辺長比 $x: y=2: 3$ の場合、据れ剛性に対寸る直交壁の寄与分は $52 \%$ であるのに対し、 $x$ : $y=3: 2$ とすると、 $84 \%$ となる。ゆえに、本論の試験体では据れ剛性 に対する直交壁の寄与分が少なく、直交壁への剛性付加が据れ応答の 抑制に対して効果を発揮しにくいと言える。

また、図 19 に示す各試験体の剛性・粘性バランスと、表 4 に示す 固有值解析で得た $h_{1}$ の関連を分析してみる。上述のように、各壁の粘 性を表す白い長方形が、剛性を表す黒の長方形と等しい長さの時、壁 単体での $h_{e q}=0.2$ となる。これより、No.1の全ての壁から分かるよ うに、耐力壁は弾性域 $\left(0.2 \mathrm{~g}\right.$ 神戸波)で小さい $h_{e q}$ を、塑性域 $(0.83 \mathrm{~g}$ 神戸 波)ではやや大きめの $h_{e q}$ を持つ。ただし、 $0.2 \mathrm{~g}$ 神戸波での応答変位は No.1 に比べて No.2 は半分程度であり (図 10), No.1, No.2 の剛側壁は同 種(合板全面壁)でありながら、No.2 の剛側壁の方が $h_{\text {eq }}$ は小さい。

K 型制振壁(No.3, No.5, No.6 の剛側壁、No.4, No.6 の直交壁)は、単 体で $25 \%$ 以上の $h_{e q}$ を有している。しかし、No.4, No. 5 , No.6では、最 も変形が大きい柔側壁の $h_{e q}$ が低いため、0.2 $\mathrm{g}$ 神戸波での $h_{1}$ は $\mathrm{K}$ 型制 振壁の $h_{e q}$ から大きく低下する(表 4)。0.83g 神戸波では耐力壁の損傷 により壁単体の $h_{e q}$ が増加するため、 $h_{1}$ も増加した。一方、方杖型制 振壁(No.2, No.3 の柔側壁)は、単体で $20 \%$ 程度の $h_{e q}$ である。No.3 は剛 側の $\mathrm{K}$ 型制振壁との組み合わせにより、 $0.2 \mathrm{~g}$ 神戸波では他の試験体に

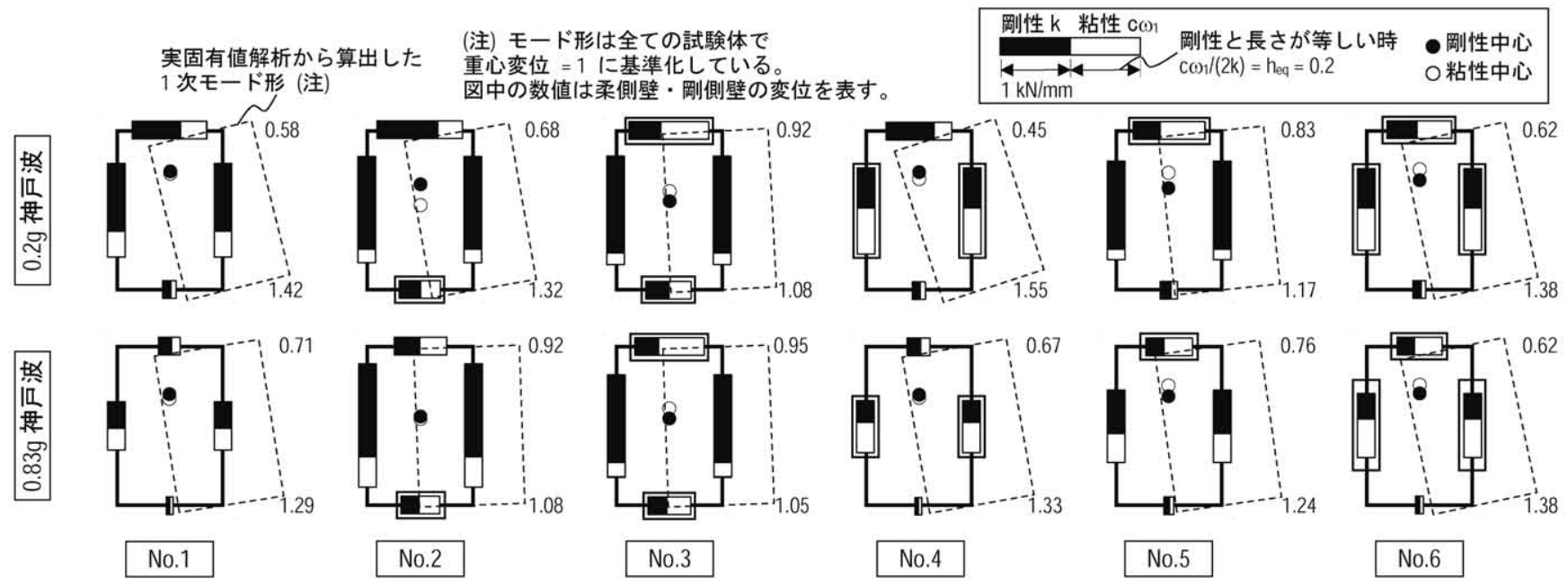

図 19 剛性・粘性のバランスと 1 次モード形 (制振壁は $\square$ で囲んで示した) 
比べ最も高い $h_{1}$ となった(表 4)。No.2 は上述したように $0.2 \mathrm{~g}$ 神戸波

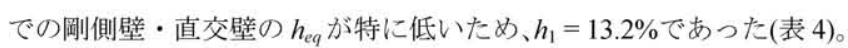
ただし、このときの No.2 の応答変位は、No.1 では $0.1 \mathrm{~g}$ 神戸波の変位 にほぼ等しく、等しい応答変位で両者の $h_{1}$ を比較すれば、No.1 は $h_{1}=$ 6.7\%であり、No. 2 はN No.1 の約 2 倍の $h_{1}$ になったと言える。このよう に、方杖型制振壁は、 $\mathrm{K}$ 型制振壁に比べて半分程度という比較的小さ い粘性でも $h_{1}$ を高めることができた。これは、モード形より明らかな ように、変形が大きい壁への粘性付加がもたらしたと考えられる。

以上より、壁単体の $h_{e q}$ だけが重要なのではなく、モード形を見て 変形が大きい䇢所に高隇衰の制振壁を与えることが、システムの $h_{1}$ の上昇に大きく寄与することを、図 19, 表 4 は表している。

\section{5 最大応答変位と等価線形化に基づくスペクトル解析}

耐力壁は変形量に応じて剛性が劣化するが、制振壁は剛性劣化が極 めて少ないため、塑性化により各壁の剛性バランスが変化する(図 19)。 本節では、塑性化の進展により各試験体の最大応答変位の分布がどの ように変化するのか分析するため、並進応答 $u_{x}=\max$ のきき、並進 応答に対する据れ応答の比を $\Delta_{1}\left(=\theta\left(L_{y} / 2\right) / u_{x}\right)$ と表し、各試験体で 比較をする。この $\Delta_{1}$ は、並進に対する据れの相対的な大きさを表す 無次元量である。また、2 次モード応答の寄与が小さく、さらに非比 例減衰による複素モード化の影響が小さければ ${ }^{12}$ 、式(6)の 1 次固有べ クトル形状が、試験体の最大応答変位分布に相似形になると考えられ る。したがって、各壁の剛性と式(6)から、固有値解析に基づく $\Delta_{1}$ の解 析值が求まり、異なる 2 種の手法から $\Delta_{1}$ を得ることができる。

実験および固有值解析による $\Delta_{1}$ の比較を図 20 に示寸。各試験体に ついて左から $0.1 \mathrm{~g}$ 神戸波、 $0.2 \mathrm{~g}$ 神戸波、 $0.2 \mathrm{gTaft}$ 波、 $0.6 \mathrm{~g}$ 神戸波、 $0.83 \mathrm{~g}$ 神戸波の順に示した。まずは各試験体の塑性化に伴う $\Delta_{1}$ の実験值の変 化について述べる。

No.2のような柔側壁へのダンパー付加は、弾性時に多少剛性中心が 重心から離れていても、剛側耐力壁が塑性化により剛性劣化し、次第 に剛性中心が重心に近付く。よって塑性域では $\Delta_{1}$ が大きく低下する。 逆に、No.5, No.6 のような剛側壁へのダンパー付加は、柔側耐力壁の 塑性化により、剛性中心が重心からさらに離れるため、他の試験体の ように $\Delta_{1}$ が低下しない。また、0.83g 神戸波でNo.1 は全ての壁の剛 性が劣化したが、No.4では直交制振壁の剛性劣化が少ない。したがっ て、直交壁へのダンパー付加は、柔側耐力壁や剛側耐力壁の剛性劣化 を防ぐことはできないが、据れ剛性に対する直交壁の寄与分を保持す ることができ、 $\Delta_{1}$ が弾性時より大きく低下する。

次に、 $\Delta_{1}$ の実験値と解析值を比較する。全体的に両者は良い対応を 示したことが分かる。つまり、非比例堿衰の程度にもよるが、最大応 答変位の分布は、剛性配置でほぼ決定され、実固有值解析から求まる 1 次モード形によって推定できることを、図 20 は表している。

これより、最大応答を与える変位べクトル $\mathbf{u}_{\max }$ (式 $\left.3 \mathrm{a}\right)$ は、 4.2 節の 等価線形化で得た 1 次モードの動的特性を用い、次式より得られる。

$$
\mathbf{u}_{\max }=\beta_{1} \phi_{1} S_{d}\left(\omega_{1}, h_{1}\right)
$$

並進応答と据れ応答の割合は、右辺の刺激関数 $\beta_{1} \phi_{1}$ が決定し、こ れは剛性バランスが支配する。また、これら並進応答と㨭れ応答の絶 対量は、変位スペクトル $S_{d}$ が決定し、 $\omega_{1}$ および $h_{1}$ により決まる。式 (8)を用いて重心の最大変位 $u_{x, \text { max }}$ の予測を行った結果を図 21 に示寸。 図 20 と同様に各地震波での精度を示しており、20\%以内でばらつき

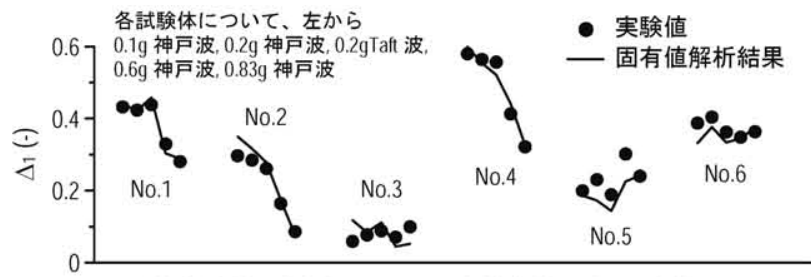

図 20 並進応答が最大のときの並進応答と据れ応答の比 $\Delta_{1}$ (実験值と 1 次固有ベクトルから評価した解析值の比較)

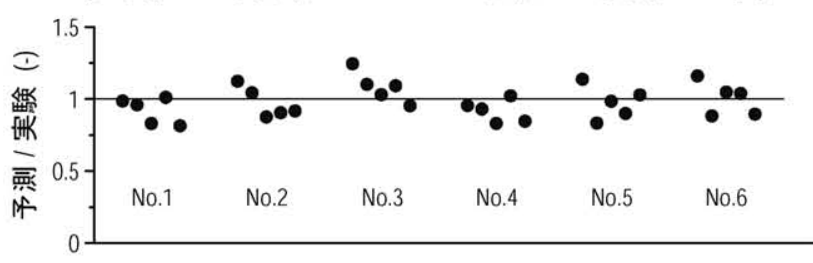

図 21 線形応答スペクトルを用いた重心変位 $u_{x}$ の予測精度

はあるものの、全試験体とも平均的に良好な精度で予測できている。 粘弾性ダンパーを用いた㨭れ応答制御法では、柔側壁や直交壁への 高い付加剛性によって、式(8)右辺の $\beta_{1} \phi_{1}$ における据れ成分を抑制し、 並進のみに近付けることができる。同時に、短周期化と付加減衰によ り $S_{d}$ を低減し、並進・据れ応答をともに減少させる。つまり、剛性と 粘性という異なる要素をそれぞれ効果的に利用することで、局所的な 応答と系全体の応答をともに減少させることができ ${ }^{15,16)}$ 、剛性のみの 補強よりも効果的に応答制御が可能となる。

また、本論の等価線形化手法により、非線形構造の応答変位の分布 が推定可能となることも分かった。すなわち、「各壁の最大変形の計 算」,「剛性の再評価」という収斂計算を行えば、線形構造を対象とした 筆者らのスペクトル解析法 ${ }^{12)}$ へ展開も可能と考えられる。

\section{5. おわりに}

剛性偏心した木質立体架構を対象とした、粘弾性ダンパーによる据 れ応答制御法を提案し、その効果を実大振動台実験によって示した。 また、試験体の動的特性值の評価や、各壁の等価線形化により得た剛 性・粘性係数のバランスと据れ応答との関連を述べた。本論で得られ た知見を以下にまとめる。

1) 方杖型制振壁による開口部の補強は、剛性偏心の矯正と短周期化、 付加滅衰により、並進応答と据れ応答をともに抑制できる。

2) 本論で提案した等価線形化に基づく固有値解析より得られる動的 特性は、線形理論による伝達関数から得られる值に比べて $T_{1}$ は長 めに、 $h_{1}$ は大きめになる傾向がある。これらに基づくスペクトル 解析では、実験の最大変位を高精度で予測でき、非線形構造への 適用が可能であることが分かった。

3) 並進応答と㨭れ応答の割合は、剛性バランスが支配し、実固有値 解析から求まる 1 次モード形により推定できる。

4) 柔側壁へのダンパー付加は、剛側壁のみ塑性化により剛性劣化し、 次第に剛性中心が重心に近づく。直交壁へのダンパー付加は、㨭 れ剛性に対する直交壁の寄与分を保持することがでる。よって、 塑性域でのモード形が弾性時よりも並進のみに近づく。

5) 粘弹性ダンパーを用いた据れ応答制御法では、適切な壁への付加 剛性によりモード形の据れ成分を抑制し、同時に、短周期化と付 加減衰により並進・据れ応答をともに減少させることができる。 
特に、変形が大きい柔側壁へのダンパー付加は、付加減衰により $h_{1}$ を高める効果が優れており、有効な手法である。

最後に、本論で対象とした構造は、水平構面の剛床を仮定したこと を再度述べておく。剛床では㧖れが生じたときに剛側壁・直交壁もあ る程度有効に働くが、いわゆる柔床の場合、剛側壁・直交壁の制振化 は効果が薄くなることが予想される。より一般的なモデルでも本論で 得た知見が有効であるのか、検証する必要がある。

\section{謝辞}

本論の振動台実験を行なうにあたり、東急建設株式会社技術研究所 豊嶋学氏, 三輪晋也氏, (株)住宅構造研究所 金井建二氏, 加治佐功氏 には多大なご尽力を頂きました。ここに記して感謝の意を表します。

\section{参考文献}

1) 日本建築学会他: 阪神・淡路大震災調查報告 建築編- 4 , 阪神・淡路大震災 調查報告編集委員会

2）村上雅英, 田原賢, 藤田宜紀, 三澤文子：阪神・淡路大震災にみる在来木 造都市型住宅の問題点, 日本建築学会構造系論文集, 第 481 号, pp.71-80, 1996.3

3) 笠井和彦, 坂田弘安, 和田章, 宮下健：K 型ブレースによるシアリンク制振 架構老用いた木質架構の動的挙動, 日本建築学会構造系論文集, 第 598 号, pp. $51-59,2005.12$

4) 坂田弘安, 笠井和彦, 和田章, 宮下健：合板パネルによるシアリンク制振 架構を用いた木質架構の動的挙動に関する実験研究, 日本建築学会構造系 論文集, 第 594 号, pp.65-73, 2005.8

5) 坂田弘安, 笠井和彦, 和田章他 4 名：速度依存ダンパーをもつ木質架構の 振動台実験，日本建築学会構造系論文集，第 615 号, pp.161-168, 2007.5

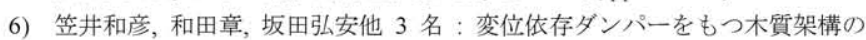
振動台実験, 日本建築学会構造系論文集, 第 594 号, pp.101-110, 2005.8

7) 坂田弘安, 笠井和彦, 大木洋司, 松田和浩：在来軸組戸建木造住宅老対象 とした 2 層木質制振架構の振動台実験, 日本建築学会構造系論文集, 第 631 号, pp.1607-1615, 2008.9

8) 野口弘行, 大浦和香子, 吉田傑他 2 名：偏心を有寸る木質建物の粘弹性夕 ンパーによる地震応答制御 立体模型による振動台実験と応答構造の分析, 日本建築学会構造系論文集, 第 600 号, pp.123-130, 2006.2

9）例えば, 赤名淳平, 曾田五月也：既存木質構造の圧効きオイルダンパーに よる耐震補強 その 1 オイルダンパー単体の性能実験, 日本建築学会大会学 術講演梗概集, B-2 分冊, pp. 105-106, 2004

10) 腰原幹雄, 阿川将樹, 大橋好光他 2 名：偏心を有寸る木質面材耐力壁構造 の静的挙動に関する実験的研究, 日本建築学会構造系論文集, 第 558 号, pp. 165-171, 2002.8

11）阿川将樹, 腰原幹雄, 佐藤孝浩他 2 名 : 偏心を有寸る木質面材耐力壁構造 の動的性状に関寸る実験的研究, 日本建築学会構造系論文集, 第 558 号, pp. 157-164, 2002.8

12）笠井和彦, 山下忠道, 山崎義弘, T. IGUSA：㨭れ振動をともなう 1 層高減衰 構造のスペクトル応答予測法, 日本建築学会構造系論文集, 第 636 号, pp.225-234, 2009.2

13) 笠井和彦, 寺本道彦, 大熊潔, 所健 : 粘弹性体の温度 - 振動数 - 振幅依存を 考慮した構成則 (その 1 線形領域における温度・振動数依存のモデル化), 日本建築学会構造系論文集, 第 543 号, pp.77-86, 2001.5

14) 笠井和彦, 大熊潔: 振動数に依存寸る制振構造の等価周期・等価減衰の評 価法とその精度, 日本建築学会構造系論文集, 第 580 号, pp.51-59, 2004.6

15) 笠井和彦, 元結正次郎, 大木洋司 : 水平地震動を受ける空間構造への粘 弾性ダンパーの適用と応答性状に関する一考察，日本建築学会構造系論 文集, 第 561 号, pp.125-135, 2002.11

16) 笠井和彦, 大原和之: 速度依存制振構造の設計, 2000 パッシブ制振構造 シンポジウム論文集, 東京工業大学建築物理研究センター, pp.293-307, 2000.3

\section{付録 1。壁倍率の算定}

壁倍率の算定には特定変形角時の耐力、降伏耐力、最大荷重の $2 / 3$, および終 局耐力と勒性から決まる最小值により決定されるが、本論では特定変形角 (1/120rad.)時の耐力のみを用いて壁倍率と称している。

付録 2. $M(x)$ と $M(x)$ の符号について

3.2 節で示した $M^{(x)}$ と $M^{(y)}$ は、ある $\theta$ に対して異符号となり、相殺するような 挙動を示した。このような現象が生じる条件を示す。

図 $\mathrm{A} 1$ に示すように、柔側壁・剛側壁・直交壁の剛性をそれぞれ $\alpha k, k, \beta k$, 試験 体の $x, y$ 方向の辺長を $L, \gamma L$ とおく。4.4 節で述べたように、粘性力により応答 変位の分布は変わらないと考え、系に剛性のみ考慮した 1 次モード形に比例寸 る変位が生じたとき、柔側壁・剛側壁の反力 $F_{x 1}, F_{x 2}$ は以下のように表される。

$$
F_{x 1}=\alpha k\left\{\phi_{11}+\phi_{21}\left(L / 2 r_{m}\right)\right\} \quad, \quad F_{x 2}=k\left\{\phi_{11}-\phi_{21}\left(L / 2 r_{m}\right)\right\}
$$

上式と式(2c)から、 $M^{(x)}$ が求められる。式(7)より $\phi_{11}, \phi_{21}>0$ を仮定しており、 $M^{x)}$ $>0$ であれば、 $M^{(x)}$ と $M^{x}$ は同符号となる。このような条件を $\alpha, \beta, \gamma$ を用いて表 せば、

$$
\frac{1+\gamma^{2}}{3}\left\{1-\frac{3\left(1+\alpha+2 \beta \gamma^{2}\right)}{(1+\alpha)\left(1+\gamma^{2}\right)}-\left(\frac{1-\alpha}{1+\alpha}\right)^{2}\right\}+1>0
$$

式(A2)において、 $\gamma=0.67,1,1.5$ とした時に $\alpha, \beta$ が満たす頒域を図 $\mathrm{A} 2$ に示 した。 $0<\alpha<1$ より、 $\alpha$ が 1 に近く、 $\beta, \gamma$ が小さいほど、 $M^{(x)}>0$ となりやす い。本論の試験体は $\gamma=0.67$ であり、 $0.2 \mathrm{~g}$ 神戸波入力時における各試験体 $\sigma \alpha, \beta$ を図 A2 に併せて示すと、全て $M^{(x)}<0$ となることが分かる。

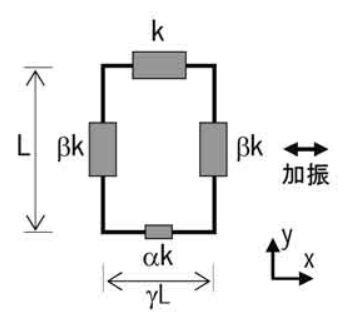

図 A1 対象とする構造モデル

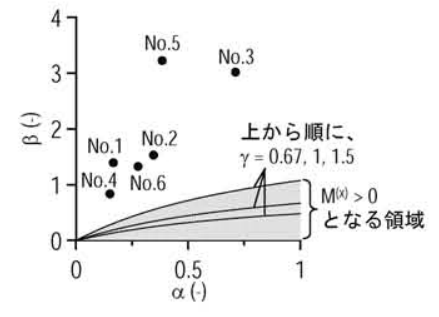

図 A2 $M^{(x)}>0$ となる領域

\section{付録 3. 非比例減衰が固有周期と減衰定数に与える影響}

本論では割愛したが、非比例減衰を考慮した理論伝達関数のカーブフィット による評価も別途行っている。その結果、比例減衰を仮定した場合と比較して、 $T_{1}$ は 0.97 から 0.99 倍と微量ながら小さめに評価され、 $h_{1}$ は減衰が小さい時に 0.84 から 1.3 倍と多少ばらつく結果もあるものの、ある程度高減衰になると概 ね等しい值となった。したがって、本論で対象とした構造モデルでは、固有周 期と減衰定数が非比例減衰の影響によって大きく変動することは無いと考えら れる。ただし、粘弾性ダンパーではなく、剛性をほとんど持たない粘性系ダン パーを用いた場合にはこの限りではなく、別途検証が必要であろう。

\section{付録 4. システムの 1 次減衰定数と粘性配置の関係}

文献 12)で述べたように、非比例減衰系においてもモード歪エネルギー法の概 念に基づき、1 次モードの減衰定数を次式より算出する。

$$
h_{1}=h_{x} \frac{\omega_{x}}{\omega_{1}} \frac{\phi_{11}^{2}-2 \vec{e}_{y} \phi_{11} \phi_{21}+\left(h_{\theta} / h_{x}\right)\left(\omega_{\theta} / \omega_{x}\right) \phi_{21}^{2}}{\phi_{11}^{2}+\phi_{21}^{2}}
$$

上式の $\bar{e}_{y}^{\prime}, h_{\theta} / h_{x}$ は文献 12)で定義した 4 種の㧖れの支配特性值のうち、粘性に 関する 2 種パラメータである。それぞれの物理的な意味は、 $\bar{e}_{y}^{\prime}=$ 粘性偏心の大 きさ、 $h_{\theta} / h_{x}=$ 据れに対する粘性抵抗の大きさであり、各壁の粘性の大きさと 位置や、質量分布より求まる。また、式(A3)より $h_{1}$ を高めるための粘性配置法 が分かる。本論のように、1 次モードの㨭れ成分 $\phi_{21}$ が大きい構造を対象とした 場合、 $h_{\theta} / h_{x}$ を高め、 $\bar{e}_{y}^{\prime}$ を低下 $\left(\bar{e}_{y}>0\right.$ のため)させることが必要となる。これ らを物理的に解釈寸れば、それぞれ建物外周部や直交方向に粘性要素を配置す ること(試験体 No.4, No.6)、剛性中心とは逆側に粘性中心を寄せること(同 No.2) である。また、No.5 のような剛側壁を制振化する手法は、 $h_{x}$ を高める一方で $\bar{e}_{y}^{\prime}$ も増加寸るため、 $h_{1}$ の上昇が鈍くなる。 